\title{
Increasing Waterflood Reserves in the Wilmington Oil Field Through Improved Reservoir Characterization and Reservoir Management
}

\author{
Quarterly Report \\ January 1 - March 31, 1997 \\ By: \\ Roy Koerner; Don Clarke \\ Scott Walker; Chris Phillips \\ John Nguyen; Dan Moos; Kwasi Tagbor
}

Work Performed Under Contract No.: DE-FC22-95BC14934

\author{
For \\ U.S. Department of Energy \\ Office of Fossil Energy \\ Federal Energy Technology Center \\ P.O. Box 880 \\ Morgantown, West Virginia 26507-0880
}

By

City of Long Beach

Department of Oil Properties

Long Beach, California 90801 


\section{Disclaimer}

This report was prepared as an account of work sponsored by an agency of the United States Government. Neither the United States Government nor any agency thereof, nor any of their employees, makes any warranty, express or implied, or assumes any legal liability or responsibility for the accuracy, completeness, or usefulness of any information, apparatus, product, or process disclosed, or represents that its use would not infringe privately owned rights. Reference herein to any specific commercial product, process, or service by trade

name, trademark, manufacturer, or otherwise does not necessarily constitute or imply its endorsement, recommendation, or favoring by the United States Government or any agency thereof. The views and opinions of authors expressed herein do not necessarily state or reflect those of the United States Government or any agency thereof. 


\section{"INCREASING WATERFLOOD RESERVES IN THE WILMINGTON OIL FIELD THROUGH IMPROVED RESERVOIR CHARACTERIZATION AND RESERVOIR MANAGEMENT"}

Cooperative Agreement Number DE-FC22-95BC14934

Tidelands Oil Production Company (TOPKO), Long Beach, CA

City of Long Beach, Department of Oil Properties

Stanford University, Stanford, CA

Magnetic Pulse, Inc. (MPI), Houston, TX

Date of Report

Award Date

Anticipated Completion Date

Government Award

Principal Investigators

Program Managers

Reporting Period
April 10, 1997

March 21, 1995

March 20, 2000

$1996 \$ 147,166$

Roy Koerner, City of Long Beach Don Clarke, City of Long Beach Scott Walker, Tidelands Oil Production Co. Chris Phillips, Tidelands Oil Production Co. John Nguyen, Tidelands Oil Production Co. Dan Moos, Stanford University Kwasi Tagbor, MPI

Roy Koerner, City of Long Beach Don Clarke, City of Long Beach Scott Walker, Tidelands Oil Production Co. January 1, 1997 to March 31, 1997 


\section{Objectives}

The objectives of this quarterly report are to summarize the work conducted under each task during the reporting period January - March 1997 and to report all technical data and findings as specified in the "Federal Assistance Reporting Checklist".

The main objective of this project is the transfer of technologies, methodologies, and findings developed and applied in this project to other operators of Slope and Basin Clastic Reservoirs. This project will study methods to identify sands with high remaining oil saturation and to recomplete existing wells using advanced completion technology.

The identification of the sands with high remaining oil saturation will be accomplished by developing a deterministic three dimensional (3-D) geologic model and by using a state of the art reservoir management computer software. The wells identified by the geologic and reservoir engineering work as having the best potential will be logged with a pulsed acoustic cased-hole logging tool. The application of the logging tools will be optimized in the lab by developing a rock-log model. This rock-log model will allow us to convert shear wave velocity measured through casing into effective porosity and hydrocarbon saturation.

The wells that are shown to have the best oil production potential will be recompleted. The recompletions will be optimized by evaluating short radius and ultra-short radius lateral recompletions as well as other techniques.

\section{Summary of Technical Progress}

\section{- Reservoir Characterization}

Work has begun on cataloguing the laboratory measurements for preparation of a final report.

\section{- Reservoir Engineering}

Researchers studied production bubble maps, injection bubble maps, cumulative production bubble maps, and cumulative injection bubble maps in order to find potential bypassed oil. Efforts were concentrated in the Upper Terminal Zone, and Tar Zone of 
Fault Block V. These efforts resulted in recompletion candidate well Z-61 which is similar to successfully recompleted DOE well $\mathrm{J}-15$. Both were recompleted in the " $\mathrm{F}_{1}$ " and " $\mathrm{F}_{\mathrm{o}}$ " sands of the Tar Zone in Fault Block V.

\section{- Deterministic 3-D Geologic Modeling}

The deterministic 3-D geologic model continues to be updated and refined. A separate report on the "Hxo" 3-D geologic model will be supplied with the "Project Evaluation Report". The model area was expanded so the horizon surfaces on the east side of the Daisy Avenue Fault could be more accurately represented. This geologic model was instrumental in the planning of the short radius redrill candidate $\mathrm{J}-17$.

\section{- Pulsed Acoustic Logging}

Discussions were held with MPI regarding the field readiness of a modified acoustic tool. MPI indicated they are not ready so there is no chance of having a modified dipole logging tool ready for testing prior to the end of budget period one (1). No further dipole logging will take place.

\section{- Recompletions}

Recompletion candidate well Z-61 has been perforated across the " $F_{1}$ " and " $F_{0}$ " sands of the Tar Zone in Fault Block V. The perforations were $0.74 \mathrm{~cm}(0.29 ")$ in size and spaced at one (1) per every other foot. Z-61 is awaiting the steam consolidation completion by a portable steam generator. Should this prove to be cost effective, other operators could contract out portable steam generators provided they have access to fresh water and fuel. Z-61 is a replacement for the ultra-short radius redrill.

Horizontal redrill candidate $\mathrm{J}-17$ was started in early March. The first attempt to hit the target "Hxo" sand failed as the trajectory coming out of the window was too high and corrections could not be made before exiting the target sand. J-17 was then plugged back and successfully redrilled to the target interval. A significant achievement in drilling this well was turning it $90^{\circ}$ while still in the target sand. The liner has been cemented in place but not perforated at this time. Rig work should be finished by the end of April. 
Researchers had a paper accepted to the June 1997 International Society of Rock Mechanics and Mining Sciences Annual Meeting titled: "Anelasticity and Dispersion in Dry Unconsolidated Sands", Chang, Moos, and Zoback.

Researchers prepared a paper for the April 1997 American Association of Petroleum Geologists (AAPG) Annual Meeting titled: "Fluid Detection and Porosity Determination using Acoustic Logs in the Wilmington Field, CA", Moos.

Researchers are working on a paper for the 1997 AAPG Pacific Section Meeting titled: "Hydrocarbon Detection Behind Casing in the Wilmington Field, CA", Moos and Walker.

The January 1997 issue of the Geophysical Research Letters published our paper titled: "Application of Theoretically derived Rock Physics Relationships for Clastic Rocks to Log Data from the Wilmington Field, CA", Moos et al.

Clarke, D., City of Long Beach: Oral presentation on "New Ways To Do Geology", PTTC Workshop on California Geology With and Without Computer Graphics, USC campus, Los Angeles, CA, 15 Jan 1997.

Phillips, C.,Tidelands Oil Production Company, Clarke, D., City of Long Beach, An, L., University of Southern California: Oral presentation on "Case Histories - DOE Supported Projects, Thermal Flood, Tar Zone, Wilmington Oil Field", PTTC Workshop on California Geology With and Without Computer Graphics, USC campus, Los Angeles, CA, 15 Jan 1997

Tidelands Oil Production Company: Discussed novel sand consolidation well completion technique developed through DOE project with John Horstkoetter, Mark Vandergon, and William Grames of BP Exploration (Alaska) Inc., Jim Spearman of BJ Services Company, and Dave Dillon of Centrilift Pumps, Inc., meeting in Long Beach, CA, 13 February 1997.

Researchers updated the project's World Wide Web homepage at 
http://pangea.stanford.edu/ moos/DOE_home.html

Final revisions are being made to the CD-ROM which describes and chronicles both DOE projects operated by Tidelands Oil.

\section{References and Publications}

None 